\title{
Recognising Adoption: Family relationships tested by birth control
}

\section{Karine-Hinano Guérin}

Translator. N. Jayaram

\section{(2) OpenEdition}

\section{Journals}

\section{Electronic version}

URL: http://journals.openedition.org/chinaperspectives/6106

DOI: 10.4000/chinaperspectives.6106

ISSN: 1996-4617

\section{Publisher}

Centre d'étude français sur la Chine contemporaine

\section{Printed version}

Date of publication: 15 March 2013

Number of pages: $53-60$

ISSN: 2070-3449

\section{Electronic reference}

Karine-Hinano Guérin, «Recognising Adoption: Family relationships tested by birth control », China

Perspectives [Online], 2013/1 | 2013, Online since 01 March 2016, connection on 28 October 2019.

URL : http://journals.openedition.org/chinaperspectives/6106 ; DOI : 10.4000/chinaperspectives.6106 


\title{
Recognising Adoption: Family
}

\section{relationships tested by birth}

\section{control}

\author{
KARINE-HINANO GUÉRIN
}

\begin{abstract}
This article is based on a survey conducted over two years in Kunming and its vicinity, as well as in the rural areas of Yunnan Province. It considers the relations between administrators (officials) and the administered (families) in the process of adoption procedures. After going over the regular, albeit little noticed, practices of adoption in China, the text analyses the interactions and negotiations that take place, case by case, as families turn towards local authorities in order to legalise the presence of a child they have acquired and taken charge of. The main focus is on the multiple and also contradictory legislative frameworks having a bearing on institutional procedures that, in view of their internal contradictions, widen the margin of manoeuvrability for local officials as well as adoptive families. The two sides thus come up with non-legal norms concerning what is best suited to such situations.
\end{abstract}

\section{KEYWORDS: adoption, law, family planning, family, legal norms, renqing / renxing.}

$\mathrm{n}$ the history of the Chinese family, adoption practices have always existed and have been prevalent in all sections of society. ${ }^{(1)}$ That is so to the present day. Everyone interviewed in China knew someone associated with adoption directly or indirectly. Nevertheless, going by official figures, the number of adoptions in China is extremely low, especially seen against a population of nearly a billion and a half: according to the Ministry of Civil Affairs of the People's Republic of China (PRC), (2) a mere 46,000 adoptions were registered in 2007: 22 percent $(10,000)$ were international adoptions, ${ }^{(3)}$ and 78 percent $(36,000)$ domestic. The official figures do not reflect reality as observed during fieldwork because the majority of adoptions are not regularised with the authorities. They take place through private arrangements and generally without recourse to a public institution such as an orphanage, which is not a place Chinese families turn to when seeking to adopt a child.

This contrast between official and actual practices stems from the difficulties met when starting the adoption process conforming to the legal measures in place. The adoption issue is framed as a legal one and is expected to mainly meet the requirements of family planning, (4) (and thus birth control jihua shengyu 计划生育): only childless couples are allowed to adopt. Nevertheless, an exception is possible through Article 8 of the Adoption Law, which allows couples with a child to adopt another one if the latter is an orphan or has been abandoned. This article gives couples who already have a child but who want to adopt the possibility of legally circumventing the one-child family planning constraint. Therefore, those seeking to adopt often leave unclear the origin of the adopted child, stating that the child was found and that they had harboured no previous plan or project for adoption.

Moreover, this elbow room for families wanting to adopt is further enlarged thanks to legal gaps as regards possession of personal documents. ${ }^{(5)}$ In fact, a child born in China does not immediately get individual documents. His or her name is written in the family's residence permit, the hukou (which labels families as agricultural or non-agricultural). ${ }^{(6)}$ Who registers the child? It is the local authority, the police station, or, before 1984, the production brigade (shengchan dui 生产队). ${ }^{(7)}$ In the case of an adoption, all that is done is to enter the child's name in the residence permit without making out personal documents. This weak legal status of the child facilitates transfer from one family to another. The fact that a person is not taken note of legally and administratively right from birth effectively gives rise to private adoptions.

Whether or not a family that adopts a child had prior intention of doing so, it does not usually inform the authorities immediately. At first a relationship is built between the family and the child taken in, establishing an effective adoption in the private sphere without making it official. However,

1. Françoise Lauwaert, Recevoir - conserver - transmettre: l'adoption dans l'histoire de la famille chinoise, Receive - nurture - propagate: Adoption in the history of the Chinese family, Brussels, Institut Belge des Hautes Études Chinoises (Belgian Institute for Advanced Chinese Studies), 1991.

2. The Ministry of Civil Affairs, acting through civil affairs bureaus in all provinces and regions, centralises adoptions across the country.

3. US citizens account for most of the children adopted from China. In 2007, they accounted for 28 percent of the 10,000 international adoptions - 5,397 adoptions were by American families. http://ouradopt.com/content/china-adoption-statistics (consulted on 8 January 2013). That same year, a mere 176 adoptions were by French families. Statistiques du secrétariat général de l'autorité centrale pour l'adoption internationale année 2007 (Statistics from the general secretariat of the central authority for international adoption, 2007), ministère des Affaires étrangères et européennes (Ministry of Foreign and European Affairs), www.agence-adoption.fr/ home/IMG/pdf/chiffres_adoption_2007.pdf (consulted on 8 January 2013).

4. "Family planning" is translated as "jihua shengyu" literally "planning births," implying control of births/birth rate in general. "Family planning" is entirely a public measure, affecting private issues to do with the founding of a family. Numerous family planning bureaus have been established throughout the PRC at all administrative levels: province / autonomous region, city, township, xiang, and village.

5. The birth of a child is not systematically registered with the authorities, especially in rural areas where many women do not go to hospitals to give birth.

6. See Isabelle Thireau and Hua Linshan, "Les migrants et la mise à l'épreuve du système du hukou" (Migrants and the challenge to the hukou), in Études chinoises (Chinese studies), Vol. xxVIII, 2004, pp. 275-311.

7. In rural areas, the production brigade organises work and acts as the local official authority. 
sooner or later, the child integrated into the family has to figure in the residence permit of the adoptive parents. They then turn to the government to request administrative and legal recognition of the child. This act seeks to fully legitimise the adopted child's place in the family as well as citizenship of the PRC. In the majority of families interviewed, registration of the adoptee in the family permit was done a posteriori, that is to say, after the relationship was solidly built. ${ }^{(8)}$ Legalisation of the family relationship is a delicate issue for both families and the authorities. This article aims at analysing this situation.

It should be stressed that given the difficulties in the process of legalising private adoptions, families hesitate to discuss it. Moreover, the real number of adoptions (and therefore of abandoned children or those handed over) often remains hidden. During fieldwork, I sought to meet families, enter the privacy of their homes, and extract accounts of adoption experiences that had often been sorrowful. In the case of issues such as adoption, only fieldwork can unearth practices that often remain hidden because of the enforcement of family planning.

For the purpose of my study, I chose to remain in Yunnan Province from 2004 to 2007. ${ }^{(9)}$ Several accessibility difficulties cropped up, linked to different elements: families' concern over safeguarding their privacy, their reserve in discussing these events, the often-observed secrecy in the matter of adoption, and considerations for the child's future. The matter of infertility, portrayed implicitly in adoption issues, threatened family honour. But these difficulties were also due to the mostly illegal nature of the practices, lack of conformity with rules imposed for birth control, and the concealment entailed. Thus, in my initial months, it was impossible to obtain interviews with families or officials. Gaining the confidence of possible interlocutors and mobilising intermediaries between them and me proved essential to overcoming or circumventing these difficulties.

My fieldwork relied on adoptive families but also on various intermediaries (between biological families and adoptive ones) as well as officials concerned with the abandonment, handing over, and adoption of children. I worked in Yunnan Province, to be more exact in Kunming city and its environs, as well as in a rural area in the province. To complement the 50-odd interviews with mostly (two-thirds) rural interlocutors drawn from different social milieux, I also carried out an analysis of various types of administrative documents and journalistic accounts, as well as material on the Internet on these issues. However, the ethnographic study remains at the heart of this article, as the vast majority of adoption practices, which are expected to follow rigorous supervision and legal regulations, do not figure in legislative texts, administrative documents, or official statistics. This article explores in particular the precise moment when families approach the authorities in order to legalise pre-existing adoptions. ${ }^{(10)}$ At that point, it is less about exposing the adoption than about regularising an effective relationship no longer open to question.

\section{Multiplicity and complexity of laws governing the family}

Faced with adoption practices, local authorities have the responsibility to implement laws that help legalise already effectively forged relationships. In order to understand their situation, it is important to study the existing legal tools and measures. Officials need to implement not one but three distinct laws: the Population and Family Planning Law ${ }^{(11)}$ (Zhonghua renmin gongheguo renkou yu jihua shengyu fa 中华人民共和国人口与计划生育法), the Adoption Law ${ }^{(12)}$ (Zhonghua renmin gongheguo shouyang fa 中华人民 共和国收养法), and the Marriage Law ${ }^{(13)}$ (Zhonghua renmin gongheguo hunyin fa 中华人民共和国婚姻法).

\section{Family Planning Law}

The Population and Family Planning Law was adopted on 29 December 2001 during the $25^{\text {th }}$ meeting of the 9th National People's Congress Standing Committee and took effect on 1 September 2002, or 23 years after the launch of the one-child policy (shengyu hua 生育化) ${ }^{(14)}$ in 1979. (15) It elaborated a legal framework for implementing the national policy on population, a basic policy that had previously lacked a legal frame apart from some principles set out in the Constitution. The law deems family planning a duty for all Chinese citizens, who have both rights and responsibilities in this task and are equally answerable as husband and wife for effective observance.

Current family planning policies encourage delaying marriage and procreation; childbirth outside the family planning framework, early marriage, and childbirth outside marriage are prohibited. Birth control policies stipulate no more than one child per couple. Nevertheless, couples in rural areas whose first child is a girl and who are in a situation judged difficult, couples who are themselves only children, those whose first child is disabled (physically and/or mentally), and remarried couples (widows and widowers or divorcees) who have just one child between them are allowed a second one. Conditions required for authorisation of a second childbirth differ from place to place. ${ }^{(16)}$ The law prohibits couples from putting their own children up for adoption as well as illegal adoptions. Thus, family planning rules seek to combat all the stratagems families might use to have extra children through such practices as abandonment, gift, and adoption. The government disallows the use of abandonment or adoption for deciding the composition of a family (abandoning a girl in order to try for a boy) or obtaining an extra child, that is, one uncovered by planning rules (adopting a child through private arrangements made directly or indirectly with the biological family):

Article 22: A woman of childbearing age who gives birth with the objective of giving the child to someone else, having transgressed the law, is prohibited from giving birth again. ${ }^{(17)}$

8. It is often when parents need to worry about schooling for the child that they get around to registration on their residence permit, the hukou.

9. Accessibility is important for fieldwork when it touches on such sensitive practices. For this reason, I chose a region I had the best access to, with a network of acquaintances.

10. My doctoral thesis tackled the various steps of the adoption process, in order to grasp the challenges of the legalisation of an adoption and its echoes to the early development of the family's emotional ties to the child. See Adopter en Chine contemporaine: La filiation à l'épreuve du contrôle de la natalité, (Adopting in China today: Relationships tested by birth control), PhD dissertation under Isabelle Thireau's supervision, defended on 8 July 2010 at EHESS, Paris.

11. Zhonghua renmin gongheguo renkou yu jihua shengyu fa, Beijing, Falü chubanshe, 2002, 14 pp.

12. Zhonghua renmin gongheguo shouyang fa, Beijing, Falü chubanshe, 1991, 14 pp.

13. Zhonghua renmin gongheguo hunyin fa, Beijing, Falü chubanshe, 1981, 14 pp.

14. "Shengyu hua" means transforming natality.

15. It took more than 20 years to come up with this law composed of seven chapters and 47 articles detailing incentives, coercive measures, and implementation of population control.

16. For instance, the relevant articles in Yunnan Province are much more severe than in Shanghai, where permission for a second childbirth is easier to obtain as population ageing is more acute.

17. All extracts of texts in this article were translated from the Chinese original by the author. This Article 22 is from Yunnan sheng renkou jihua shengyu tiaolie (Rules concerning population and family planning in Yunnan province), www.yn.gov.cn/yunnan,china/72908646102597632/ 20060224/1046918.html (consulted on 31 March 2010, not accessible on 15 February 2013). 
Many unplanned children go unregistered and are referred to as "black children" (hei haizi 黑孩子). While the officially estimated fertility rate is a low 1.8 per woman, it is open to question: experts say 20 million to 30 million children stay hidden from the authorities, mainly in rural areas. Birth control has led to a veritable rise in the floating population. During birth control enforcement, driven by teams in charge of family planning, a rise in abandonments was noted ${ }^{(18)}$ by all social actors I met - those engaged in hospitals, orphanages, or civil affairs bureaus. ${ }^{(19)}$ As it is impossible (due to financial constraints) to know the sex of the child to come, parents can only decide after birth whether to separate from a newborn based on the sex. Thus, parents abandon or give away their girl child in order to seize another opportunity to have a boy. ${ }^{(20)}$ Family planning implementation differs according to local conditions (from one region, city, or even village to another), but mainly because of people's difficulties in accepting the details. In such a situation, adoption takes a major place in the Chinese family today. (21)

\section{Adoption Law}

Along with the family planning law, the one on adoption governs these practices. The first Adoption Law of the People's Republic of China was promulgated on 29 December 1991 during the $23^{\text {rd }}$ meeting of the $7^{\text {th }}$ National People's Congress Standing Committee. It was revised on 4 November 1998 during the $5^{\text {th }}$ meeting of the $9^{\text {th }}$ NPC Standing Committee. It aimed to protect legal adoptive relations as well as safeguard the rights of the parties concerned. It is clearly stipulated that adoption must take place in the interests of the adopted minors' education. The importance of family planning is affirmed in article 3 :

Adoption shall not contravene laws and regulations on family planning. (22)

In Chapter 2, entitled "Establishment of an adoptive relationship," articles 4,5 , and 6 define respectively the identity of children who can be legally adopted, those who may offer a child for adoption, and those adopting:

Article 4: Minors under the age of 14 , as enumerated below, may be adopted:

(1) orphans bereaved of parents;

(2) abandoned infants or children whose parents cannot be ascertained or found; or (3) children whose parents are unable to rear due to unusual difficulties (teshu kunnan 特殊困难).

Article 5: The following citizens or institutions shall be entitled to place out children for adoption:

(1) guardians of an orphan;

(2) social welfare institutions (shehui fuli jigou 社会福利 机构) ; or

(3) parents unable to rear their children due to unusual difficulties.

Article 6: Adopters shall meet simultaneously the following requirements:

(1) childless;

(2) capable of rearing and educating the adoptee;

(3) suffering no disease medically regarded as unfit for adopting a child; and

(4) having reached the age of 30.
Article 7 deals with the issue of adoption within the same family circle. In this instance, the law does not require that natural parents be incapable of rearing their child due to unusual difficulties. Such adoption may stem from mutual consent between natural parents and adoptive ones if they belong to up to three generations within the same family. Such adoption takes place through an adoption agreement (shouyang hetong 收养合同) between natural and adoptive parents. If the adoptee is over 14 , his or her consent is needed.

Article 8 (cited in the introduction) says a person may adopt one child only, male or female, but goes on to add an important derogation:

Orphans, disabled children, or abandoned infants and children whose parents cannot be ascertained or found and who are under the care of a social welfare institution may be adopted irrespective of the restrictions that the adopter shall be childless and that he or she may adopt one child only.

In these specific cases, the person adopting need not be childless and may even be able to adopt more than one child. Article 8 thus removes the heaviest restriction on the adopting individual - of having to be childless - and thus constitutes a breach in the one-child policy. It allows elbow room for those seeking to skirt family planning rules and have more children. However, this article is not systematically applied. Indeed, independently of birth control measures, the family planning bureau generally requires that the adoptive family pay a fine for unplanned birth in order for the adoptee to be registered on the residence permit.

Article 19 spells out the warning set out in article 3 that "adoption shall not contravene laws and regulations of family planning":

Persons having placed out a child for adoption may not bear any more children, in violation of the regulations on family planning, on the ground of having placed out their child for adoption.

Through this article, the government targets those who give away a child (generally a girl) for adoption in order to open up the possibility of giving birth to a son. The government is fully aware of the strategies people may adopt in resisting birth control. Article 20 stresses, moreover: "It is strictly forbidden to buy or sell a child or to do so under the cloak of adoption." The authorities thus seek to counter adoption practices based on private arrangements. They are not unaware that some people go to the countryside or the suburbs seeking children to adopt. Using adoption to skirt family planning restrictions and have an additional child is strictly illegal. The authorities have also cracked down on families that pretended to have found a child along the roadside whereas in reality they had intentionally acquired the child through adoption.

18. See Kay Ann Johnson, "The Politics of the Revival of Infant Abandonment in China, with Special Reference to Hunan," Population and Development Review, No. 22, March 1996, pp. 77-98.

19. Chinese orphanages' charges are 98 percent girls, and the boys there are generally handicapped (mentally or physically).

20. Parents are determined to have sons as they represent the only possibility of support in their old age in a country where there is almost no social cover - especially in rural areas where land is passed on through males and it is the son's duty to care for aged parents. A son is also a must for performing ancestor worship rites.

21. Kay Ann Johnson, Wanting a Daughter, Needing a Son: Abandonment, Adoption and Orphanage Care in China, St. Paul Minnesota, Yeong \& Yeong Book Company, 2004.

22. Article 3, Zhonghua renmin gonghe guo renkou shouyang fa (Adoption Law of the People's Republic of China), Beijing, Falü chubanshe, 1998, p. 8. 
Article 15 deals with the formalities needed to establish an adoptive relationship. In reality, formalities follow an adoption, whereas according to the law, it should absolutely be the other way around:

The adoption shall be registered with the civil affairs department of the people's government at or above the county level. The adoptive relationship shall be established as of the date of registration.

(1) When an abandoned infant or child whose biological parents cannot be ascertained or found is adopted, the civil affairs department in charge of registration shall make a public announcement prior to the registration.

(2) If the parties involved in the adoptive relationship wish to enter into an agreement on adoption, they may conclude such an agreement.

(3) If the parties or one party involved in the adoptive relationship wishes that the adoption be notarised, it shall be done accordingly.

Provisions (1) and (2) of Article 15 indicate that an adoptive relationship cannot be forged until it is registered with the authorities, especially the civil affairs bureau concerned. Only after official registration can an adoptive relationship begin. Thus, a relationship forged independently of the authorities is forbidden. Chapter 2 of the Adoption Law ends with Article 22 concerning the secrecy issue in such relationships:

When the adopter and the person placing out the child for adoption wish to make a secret of the adoption, others shall respect their wish and shall not make a disclosure thereof.

The law thus protects the parties' wish to keep a lid on the adoption. While prohibiting adoptions stemming from private arrangements, the law defends the intimate and secret dimension in adoption practices: once registered with the authorities, it must not be revealed to others.

\section{Marriage Law}

The Marriage Law (which will be briefly dealt with here) also governs adoption practices. ${ }^{(23)}$ Like the Adoption Law, the Marriage Law of the PRC underlines the importance of birth control, the government insisting and recommending that couples have one child of "good quality." (24) Although the marriage law is not as much cited in adoption matters, it is fundamental in that it rules on the rights and duties of those belonging to the same family. It sets out each person's responsibility with regard to the care of elderly people but also the protection of children. Any practice of abandonment is officially forbidden. Rights and duties governing parents and children are clearly stipulated, and each party is mutually linked to the other in a relationship that is made effective through respect for these rules. Article 26 touches on adoption, declaring that the rights and duties in a relationship forged through a legal adoption are identical to those in a blood relationship:

The state shall protect lawful adoption. The relevant provisions of this law governing the relationship between parents and children shall apply to the rights and duties in the relationship between foster parents and foster children.

The right and duties in the relationship between a foster child and his or her natural parents shall terminate with the establishment of this adoption.
Three principal laws thus govern the practices of abandonment, giving away, and adoption of children in China: Family Planning Law, Adoption Law, and Marriage Law. As birth control is a state policy, the Family Planning Law largely dominates the supervision of these practices. Any practice of giving away a child or adopting one is permitted so long as it does not transgress family planning arrangements. The Adoption Law has less of a bearing on these practices than does the Family Planning Law. But the former's Article 8 offers a legal breach that helps skirt birth control measures, as it opens the possibility for those who are already parents to adopt a child who is an orphan or has been abandoned. Families therefore prefer telling the authorities that they had no intention of adopting but happened to stumble upon an abandoned child. (25) However, irrespective of the origin of the adopted child, recognition of this relationship by the authorities remains essential.

\section{Chinese officials' dilemma}

Officials in charge of regularising adoptions a posteriori function mainly in the family planning bureaus (jihua shengyu ju 计划生育局) and civil affairs bureaus (minshi ju 民事局). They have to implement different laws and face difficulties in the process, given the schematic and complex, sometimes even incoherent, nature of the legal framework imposed, as will be discussed now.

\section{Difficulty in implementing laws}

As part of adoption procedures, concerned officials have to first make enquiries with the families. They have to verify whether the adoption in question is in conformity with the law, especially that concerning family planning. They are expected to ensure that practices fall within a legal framework, although the use and interpretation of laws in different situations is by no means easy.

To start with, local cadres could well have a poor understanding of the law. The laws are also so succinct as to offer a margin of interpretation to those charged with implementing them. In other words, these various laws are not grasped and applied uniformly by everyone. In fact, officials on the ground often come up with varied interpretations based on convenience. For example, given the ambiguities in Article 8 of the Adoption Law, it is applied in very different ways. Some do not take it into account and impose a fine for having a second child disregarding family planning; others take Article 8 into account and impose no fine without seeking to verify whether or not the adopted child was indeed abandoned or orphaned. Often a doubt (harboured deliberately by authorities) persists as regards the adopted child's origin.

More specifically, when faced with private adoption practices, each administrator - of the family planning bureau, civil affairs bureau, or police follows a particular reasoning and reaches assessments and evaluations deemed relevant given the understanding of the situation. Such reasoning and evaluation, whether simple or complex, rely on official dispositions but

23. Karine-Hinano Guérin, "Mariage," in Thierry Sanjuan (ed.), Dictionnaire de la Chine contemporaine (Dictionary of contemporary China), Paris, Éditions Colin, 2007.

24. From the government's viewpoint, the application of family planning goes side by side with ensuring the quality of births: there had to be fewer births but the infants had to be of good quality. From this came the slogan in the early 1980s: "Fewer and better births" (shao sheng you yu 少生优育).

25. This study considered mostly private adoptions, those arrived at following non-official arrangements between natural and adoptive families using one or more intermediaries. 
also each official's good sense. Thus, three distinct arguments on the part of local cadres came to light during fieldwork:

- Some consider the adoption of an "abandoned" child to be an altruistic act and one that lightens the state's burden.

- Others hold that this action is far from well-meaning but rather is selfserving and in contravention of what family planning officials require.

- Many others refuse to dwell on the intentional or non-intentional character, or self-serving or altruistic nature of the adoption: the issue is merely one of applying birth control measures as convenient.

The diverse actions of those in charge of applying the law stem from these different rationales, even if there is no systematic link between the argumentation and the actions that follow. For example, two officials might have similar thoughts about the adoption issue, but in a given situation will act differently. ${ }^{(26)}$ Thus, when officials consider an adoption to be altruistic, they may adopt several stances. In general, officials close their eyes to an adoption that has taken place: they pretend ignorance as to how it has come about and issue no document regarding the adopted child's existence. In rare cases they agree to register the child. In all cases, they do not report an "illegal" adoption to their superiors, as they wish to avoid getting entangled in the matter. They believe their work has been rendered difficult but refuse to punish the adoptive family. One official explained that unfortunately he lacked the power (quanli 权力) to regularise a child's presence in the family but had decided not to pursue his enquiries as it concerned "wellmeaning people" (shanliang ren 善良人):

They already have to spend a lot to bring up this child who is not theirs. I'm not going to add to their difficulties, but I don't have the power to carry out the formalities in respect of the child. (27)

Those who choose to register the child sometimes explain that they do not want to add to the floating population:

It is better to register ... Anyway, he is there, he won't be killed, he is there, and well, he's part of Chinese people. Better to register him to reduce the floating population. If that is not done, it is not possible to control the population. ${ }^{(28)}$

If a fine is not set but the family works out a private arrangement with the official, ${ }^{(29)}$ the child is registered in the adoptive family's residence permit and the relationship recognised, without, however, a mention of the adoption:

They have expressed their good intentions. They cannot pay a fine right now. We have known each other for a long time ... But, they will pay a fine when they are able to. ${ }^{(30)}$

But when the adoption is considered self-serving and deliberate, in general a fine covering a birth outside family planning rules is imposed. So long as the fine is not paid, the official refuses to register the child:

They are privileged, they absolutely want another child; that is why they must compensate the Chinese people for the extra resources they will need for this child. It is our national policy. ${ }^{(31)}$

Once the fine is paid, the child is registered, with or without a mention of the adoption effected. ${ }^{(32)}$ It can also happen that once the fine is cleared by those adopting, the official in charge may not be able to begin the formalities, as he is ignorant of the procedure to follow in such a situation:

I don't know what has to be done. I have to wait for directives. They have violated family planning and have made social compensation, but have no right to adopt. They already have many children. I don't know whether they really found this baby. For now I'm waiting for directives. What is important is to apply state policy. So long as they respect family planning, they can do as they please. If the state has to regularise every child adopted, everyone would abandon their children ... (33)

Some officials do not consider the circumstances of the adoption but the sole issue of whether the adoption is or is not in conformity with the requirements of the birth control policy. If the adopting family has no other child, the adopted one is registered; if there already is a child, the adoptee is not registered. Some go so far as to encourage the parents to take the child to an orphanage. However, I have not come across any case where force was used to impose such a measure, or of any orphanage personnel ever going to an adoptive household to seize an illegally adopted child.

On top of this highly complex as well as simplistic nature of the legal framework, there are the rules laid down in line with local specificities and fixed by administrations on the ground. ${ }^{(34)}$ Ad hoc regulations are adopted in a particular region, township, or village. They remain valid for a limited period and are then extended or not, depending on field officials' reports to their superiors. For instance, keeping in mind the growth of the floating population in a remote region, a circular allowed families that had adopted children born between 2000 and 2003 to regularise the adoptions without being subjected to any fines. However, the extent of "irregular" adoptions is often suppressed for fear of reprisals and therefore fails to be taken into account systematically in elaborating local regulations. ${ }^{(35)}$ Besides, the officials also display their good intentions by visiting families in order to persuade them to regularise adoptions, before including them in their reports. Thus, while the regulations are tested in situations encountered on the ground, they are also, to the extent possible, readjusted to render them more satisfactory.

26. Nicolas Dodier, "Les appuis conventionnels de l'action: Elément de pragmatique sociologique" (Conventional bases of action: Elements of sociological pragmatics), Réseaux, No. 62, 1993, pp. 6385.

27. Xiao Meng, 27, employee in a family planning bureau in a small southern Yunnan township. Interviewed in September 2005.

28. Remarks of Mme Kong, former employee of a family planning bureau who now works in the divorce section of a local civil affairs bureau but retains great interest in all issues relating to adoption. Interviewed in October 2005.

29. Jean-Louis Rocca, "La confusion des devoirs. Corruption et bureaucrates en Chine à la fin de l'Empire et dans les années 1980" (Confusion of duties: Corruption and bureaucrats at the end of the Empire and in the 1980s), Revue française de science politique (French Journal of Political Science), No. 4, 1994, pp. 647-665.

30. Mme Kong's remarks. Interviewed in October 2005.

31. Xiao Meng, 27, employee in a family planning bureau. Interviewed in February 2006.

32. Fines for births outside family planning norms can vary from five to ten times the household annual income, according to measures set out in the Family Planning Law. However, in practice, private arrangements are arrived at between officials and families according to their existing resources. The levels are set to facilitate the payment of the fine.

33. Xiao Meng, 27, employee in a family planning bureau. Interviewed in February 2006.

34. Gu Baochang, Feng Wang, Guo Zhigang, and Zhang Erli, "China's Local and National Fertility Policies at the End of the Twentieth Century," Population and Development Review, Vol. 33, No. 1, 2007, pp. 129-47.

35. For instance, a circular for provision of social benefits to a certain number of families in difficulty to the extent the budget available to a village committee permits. 
Other non-legal elements also have a bearing on decisions whether or not to regularise a private adoption. The officials are in effect caught amidst several expectations, and laws are not their sole reference points.

\section{Officials torn between families and the state}

It is not just the necessity of having to implement multiple laws that makes the process of regularising private adoptions difficult: the relations between the officials and citizens are directly affected, and the obligations or understandings that mutually link them are therefore affected as well. Several cadres of the family planning bureau expressed to me the difficulties they faced in carrying out their duties in the face of complex situations, and their feelings - sometimes giving place to veritable resentment - of being caught between the requirements of the state and those of the local population they have to face daily. These cadres suffer from long-term tensions and are hurt by the anger and incomprehension of families who cannot accept that squads overseeing family planning should interfere in such private issues as their composition. Officials' resentment also stems from the fact that the laws do not always cover the situations they encounter. Be it on the families' or the officials' side, they take badly to situations seen as unjust when recognition of pre-existing relationships is considered impossible in the eyes of the state.

The administrator is also in effect an administered, (36) expected to embody a model of good conduct and show understanding as regards actions taken by families outside of official routes. So the official has to find alternatives and come up with compromises so as to regularise these private adoptions. This is why there is no systematic implementation of the law but rather a case-by-case application. The decisions taken might seem arbitrary, but they are often justified by officials' willingness to abide by directives from superiors without conforming to them totally. In most cases, the administrators dispense with all enquiries and do not even verify the origin of the adopted child so as to avoid having to make a judgment and assume unwanted responsibility. Lack of precision in the laws provides them with leeway to protect themselves from the superiors to whom they need to report: ${ }^{(37)}$

We try to implement the law, that is all. Our actions are highly constrained. We try to talk to them but they don't listen to us. They continue to give birth to several children, contravene family planning norms, and are issued fines they are unable to pay. What do you want us to do? (...) If they abandon a child, they do it elsewhere, far away, in another township. Same with adoption; people adopt if they wish, so long as they pay the fine for the extra child ... In any case, everyone says they went to look for a child in the mountains. As for us, it is none of our concern, no one is going to go and verify. ${ }^{(38)}$

Many of them confided to me their feeling of injustice born of the contradictory pressures they face from their own hierarchies and from families: they are condemned to keep bearing the limits and drawbacks of their own actions. They get caught in the contradictions existing between laws but also between the laws and the moral principles they share with the administered. They sometimes have the feeling of transgressing "human feelings" (renqing 人情) to such an extent that they prefer to ask for a transfer to another service in the government. ${ }^{(39)}$ The humanity of one side is simply opposed to that of the other:
... But of course I have encountered problems when I have gone to meet employees of the civil affairs bureau to resolve this problem. They even told me to send the child to the orphanage. They are inhuman. I oppose such reasoning... I told them I had had no intention of adopting this child, I have not adopted this intentionally and that I had not intended to get hold of this child in order to adopt. Finally, the people in the civil affairs bureau asked me what right I have to adopt and told me to send the child to the orphanage. I said: "You think the orphanage is capable of caring as much?" They replied that it was the state's problem and not mine. I find such reasoning devoid of any basis in human feelings (zhe zhong shuofa zai renxing shang mei you genju 这种说法在人性上没有根据). If everyone thought so, human hearts would turn cold; what fellow-feeling will there be among humans? Isn't it so? I have always believed that human feelings (renxing 人性) should be respected. If everyone adopted such reasoning and thought it was the state's business, there will be so many children in pitiable conditions. Take the child I collected: if we had waited for the civil affairs bureau and the orphanage to come and collect her, she would have died of cold long ago; she would no longer be in this world. ${ }^{(40)}$

Regularisation of private adoptions is that much more difficult for officials who do not want to appear unjust to families that really took on, with no prior planning, children given away or abandoned. They need to be particularly creative in applying the laws when they find themselves in situations such as that of Mme Tao.

One of my interlocutors, Mme Tao, explained how she could not bring herself to comply with birth control rules faced with the possibility of taking care of a girl child found by the roadside. As she already had a natural boy child, she was well aware of the difficulty in justifying and registering this adoption with the authorities, even though she had not had any intention of adopting in the first place:

At first it was simply a case of saving her, then she had a fever and I took her to the hospital. She had pneumonia. A life had to be saved. But little by little, I found this child to be so adorable. She was still tiny, her eyes were closed but it seemed to me she was smiling. It occurred to me then that the two of us had a common destiny. It was enough for me to be in front of her to get her smiling. Her eyes would be shut but she knew it was me. The force of destiny was present. I could not resolve it: at first I just wanted to save her life and send her to the orphanage ... Eventually feelings develop between people; the result is that I could not part with her. [...] I did, however, think it over, because according to the law, I had no right to adopt; eventually I decided to bring her up myself, whatever the burden. Nevertheless, I also thought of taking her to the orphanage [...] I felt

36. Tyrene White, China's Longest Campaign: Birth Planning in the People's Republic, 1949-2005, Ithaca and London, Cornell University Press, 2006. The book also deals with the great difficulties faced by officials of the family planning bureau.

37. Given the impossibility of meeting their superiors' demands, officials conceal real figures: "We have to write reports, supply statistics and tables to our superiors. If we do not turn in appropriate quotas, we risk losing our jobs" (interview with Xiao Yu).

38. Second interview with Xiao Meng, 27, employee in a Family Planning Bureau, in February 2005.

39. Family planning bureau employees have spoken of unbearable situations such as having to impose abortions, which might be inadvisable in the given situation or against their religious beliefs.

40. Second interview with Mme Tao, in January 2007. 
very bad, I could not make her suffer the feeling of abandonment a second time, I pitied this tiny being ... After having thought it over, I decided to raise her myself. [...] I know people in government; of course it was going to cost us a lot but we could not do otherwise [...] It took more than two years for her to be registered in our family permit. ${ }^{(41)}$

Officials encountering such situations have to deal with a number of questions. What must prevail: rigorous respect for the law or for human life? How would it be to act in a way that is most adequate (heshi) given the situation and also in conformity with the law (hefa)? The sensitivity, experience, and perceptions of those administered are then tapped in complex ways, as the need is to arrive at an interpretation and a result that is reasonable (heli) and socially approved for the practices effected outside the legal route.

Solutions tend to be conceived collectively, as they emanate from local arrangements allowing for compromises. They must satisfy both parties, that is to say, take into account the interests of the family and the adoptee as well as those of the officials. It is because solutions are defined by several people that they come to be judged acceptable. On issues as basic as implicating a human life, responsibilities quickly appear to be shared. Finally, what informs decisions is often the desire to safeguard the well-being of the adoptee as well as family intimacy without actually derailing the official adoption process.

Hence the problem for officials, who often refuse to apply laws without first reinterpreting and combining them with moral principles deemed relevant, principles that are interconnected with notions of intention and of responsibility.

\section{Between respect for the law and for human life: Assessing families' intentions and responsibilities}

More specifically, administrators are pulled between rigorous application of laws and respect for human life. The multiple interpretations that can be offered as regards laws arise essentially from the lack of clarity in Article 8 of the Adoption Law, which will be discussed once more as it throws up complex issues.

In the framework of adoption procedures, Article 8 with its characteristic ambiguities entails a reflection on issues such as the parents' intention and responsibility. Some families have long nurtured plans to adopt, and even if they never approached public institutions for the purpose, they have taken private initiatives to identify a child for adoption. Other families had no such plans but adopted a child after having found one by the roadside or having been entrusted with one out of the blue. Given the urgency of the situation, they take charge of the child and resist approaching the orphanage out of concern for the child.

The issue of families' intentions plays a particularly crucial role here. Whereas in France prospective parents have to justify their intentions with adoption services, in China, given the compulsions of birth control, couples seeking to legalise the presence of a child in their midst are constrained to come up with proof of a total absence of prior intention to adopt. Article 8 of the Adoption Law, as noted above, provides for this exception: couples who already have a child can adopt if and only if the adoptee is an orphan or a foundling. In other words, they must not have premeditated the act of adoption. Families are thus obliged to hide their real intentions in order to be able to adopt, that is to say, have an extra child and constitute a family that could be deemed ideal. How to reconcile the administration's stipulation of not accepting an adoption unless it was unpremeditated and the exigencies of the necessarily long process of building an affective and familial relationship? Some officials are taken aback when they find themselves faced with children who have already been living for a long time with their adoptive families when the latter decide to turn to local authorities. The officials have then to reconstruct, long after the event, the adoptive parents' motivations. Far from being gullible, they are alive to the families' hidden intentions. They cannot ignore this hidden intention or their responsibility towards a human life. ${ }^{(42)}$

The questions raised around the intentions of one side and the other deal with responsibility. Who is responsible for whom? To what extent? How to draw the boundaries of responsibility of officials in charge of regularising adoptions in relations to that of families? The relations between administrators and adoptive families and between the state and citizens are shaped on a daily basis depending on the answers to these questions.

\section{Conclusion}

This study has helped shed light on existing adoption practices. Recognising an adoption is a process punctuated by several steps, including the adoptees' registration with the authorities. If it is a case of regularising a relationship forged through a private adoption often not in conformity with the requirements of family planning, officials have to apply laws while also paying attention to a number of local concerns, especially respect for shared moral principles. More specifically, the complexity and ambiguity of Article 8 of the Adoption Law offers a margin of mobility for families to skirt family planning rules and leads officials to offer diverse interpretations of relevant texts and laws.

The instances of regularisation of adoptions already accomplished reveal the complexity of relations between officials and families. While trying not to deviate from the legal framework, officials have to take on board families' feelings and the urgency of the situation they find themselves in. Sometimes it has been an issue of saving a life or, in some cases, a child's life might be threatened. Officials negotiate with formal rules, sometimes going so far as to transgress them (although they do so discreetly if not secretly). The way they handle things has to be perceived locally as just and reasonable, and for this they need to base themselves on a multiplicity of normative points of reference. They need to prioritise the legal and social norms referred to. Respect for human feelings plays a fair role in putting laws to the test, resulting in their validation or even invalidation. ${ }^{433}$

The issues of necessary respect for human life and the basic needs of a human being are raised. Officials find themselves obliged to respect the relationship established between the adoptive family and the adoptee, and

41. First interview with Mme Tao, 50, head of a nursery school, in January 2007.

42. Adoptive families hold that their actions cannot be viewed in the light of Chinese citizens' duty to respect family planning regulations but rather as one of saving and deliberately taking charge of a child in an act of humanity. See Clifford Geertz, Local Knowledge: Further Essays in Interpretive Anthropology, New York, Basics Book, 1983.

43. Isabelle Thireau writes: "This requirement of humanity, the very basis of morality, becomes useful not only to judge the validity of prescriptions imposed but also to guide decisions of those in charge of respecting the prescriptions." Isabelle Thireau and Hua Linshan, "Jugements de légitimité et d'illégitimité: la vie normative dans les nouveaux lieux de travail en Chine" (Judgements of legitimacy and illegitimacy: Normative life in new workplaces in China), Revue française de sociologie, Vol. 46, No. 3, 2005, pp. 529-558. 
to adjudicate on the compassion (tongqing) and goodwill (shanliang) shown, or not shown, by adoptive families. The principles of equality as well as that of reciprocity are mobilised. Families try to make clear the special situation in which they find themselves and implore officials to put themselves in their place. The officials' individual experience and emotions will influence their decision to regularise or not regularise an established relationship. ${ }^{(44)}$

Administrators and the administered thus negotiate case-by-case to identify the best possible arrangement: one based on multiple normative principles and achieving the convergence of relevant laws and rules, of relations already established between parents and adopted children, of the personal relations sometimes existing between the local administrators and the administered, and of moral principles that need to inform the steps to be taken.

Officials try to find a compromise between the need to act in a just and equitable manner without punishing the abandoned children, those given away, and the illegally adopted so as not to encourage infractions of family planning. They have to protect society's order and public interest, cracking down on illegality, while legitimising governmental authority through the implementation of family planning policies. In other words, they are guar- antors of the rule of law. But they find themselves facing families who, while relying on shared principles, claim the right to "act properly" by rendering help to an abandoned child or by taking initiatives to arrive at a family composition judged ideal. Local officials called upon to regularise pre-existing adoptions are not unaware of the basic right ${ }^{(45)}$ that is thus invoked as a source of legitimacy. However, depending on the circumstances, they propose different compromises between law and good law.

Thus, during the 2010 census and given the magnitude of the phenomenon, officials were advised to regularise adoptions: not to systematically proceed against families for infractions of family planning rules, so as to account for adopted children who had no legal existence but who were present in many millions of Chinese households.

\section{Translated by N. Jayaram.}

I Karine-Hinano Guérin holds a Ph.D. in Chinese Civilisation and Language, as well as in Sociology.

EHESS-CECMC, 190-198 avenue de France, 75013 Paris, France (khguerin@gmail.com).

44. Nicolas Dodier, "Action as a Combination of Common Worlds," The Sociological Review, Vol. 41, No. 3, 1993, pp. 556-71.

45. Alain Cotterau, "Droit et bon droit. Un droit des ouvriers instauré, puis évincé par le droit du travail (France XIX ${ }^{\text {ème }}$ siècle)" (Law and basic rights: Right for workers established, then overruled by labour law - Nineteenth Century France), Annales, No. 6, pp. 1521- 1557. 